\title{
MANAJEMEN KEUANGAN SEKOLAH DALAM PEMENUHAN SARANA PRASARANA PENDIDIKAN (Studi kasus di SD Muhammadiyah 1 Krian, Sidoarjo)
}

\author{
Rita Pusvitasari ${ }^{1}$, Mukhamad Sukur ${ }^{2}$
}

Institut Agama Islam Negeri Tulungagung, Jawa Timur, Indonesia

Email : ritavita0919@gmail.com ${ }^{1}$, m.sukur1983@gmail.com ${ }^{2}$

DOI: http://doi.org/10.33650/al-tanzim.v4i1.959

\begin{tabular}{ll|l} 
Received: Januari 2020 & Accepted: Maret 2020 & Published: Maret 2020
\end{tabular}

\begin{abstract}
:
This study aims to analyze and understand school financial management in fulfilling educational infrastructure facilities at SD Muhammadiyah 1 Krian, Sidoarjo, East Java. This research uses a qualitative approach with case study. Informants in this study consisted of leader, secretary, and treasurer. Data collection techniques are carried out using interviews, participant observation, and documentation. The data analysis technique uses data reduction, data display, and conclusion drawing / verification. Checking the validity of the data is done through; credibility, transferability, dependability, and confirmability. The results showed that; school financial management in fulfilling educational infrastructure facilities at SD Muhammadiyah 1 Krian was carried out through; school budget planning, school budget absorption, accounting for school finances, school financial accountability. This research has implications for the importance of financial management in the fulfillment of educational facilities and infrastructures, through involving stakeholders, both internal and external, to evaluate, analyze, supervise and meet various school needs.
\end{abstract}

Key words: Financial management, infrastructure, schools

\begin{abstract}
Abstrak :
Penelitian ini bertujuan untuk menganalisis dan memahami tentang manajemen keuangan sekolah dalam pemenuhan sarana prasarana pendidikan di SD Muhammadiyah 1 Krian, Sidoarjo, Jawa Timur. Penelitian ini menggunakan pendekatan kualitatif jenis studi kasus. Informan dalam penelitian ini terdiri dari pimpinan, sekretaris, dan bendahara. Teknik pengumpulan datanya dilakukan dengan menggunakan interview, observasi partisipan, dan dokumentasi. Teknik analisis datanya menggunakan data reduction, data display, and conclusion drawing/verification. Pengecekan keabsahan datanya dilakukan melalui; credibility, transferability, dependability, dan confirmability. Hasil penelitian menunjukkan bahwa; manajemen keuangan sekolah dalam pemenuhan sarana prasarana pendidikan di SD Muhammadiyah 1 Krian dilakukan melalui perencanaan anggaran (budgeting) sekolah, penyerapan anggaran sekolah, pembukuan (accounting) keuangan sekolah, pertanggungjawaban (akuntabilitas) keuangan sekolah. Penelitian ini berimplikasi pada pentingnya pengelolaan keuangan dalam pemenuhan sarana dan prasana pendidikan melalui pelibatan stakeholders, baik internal maupun eksternal, guna mengevaluasi, menganalisis mengawasi dan memenuhi berbagai kebutuhan sekolah.
\end{abstract}

Kata Kunci: Manajemen keuangan, sarana prasarana, sekolah 


\section{PENDAHULUAN}

Keuangan merupakan komponen yang penting dalam lembaga pendidikan (Burger, 2015). Oleh karena itu, perlu adanya pengelolaan keuangan yang baik agar proses pendidikan dapat berjalan sesuai dengan tujuannya. Manajemen keuangan pendidikan memberikan atensi yang besar akan pentingnya tata kelola keuangan pendidikan dalam peningkatan program sekolah, pelaksanaan guru dalam kegiatan belajar mengajar, pelaksanaan akademis peserta didik.

Kepala sekolah sebagai perencana anggaran sekolah, harus memahami manajemen keuangan sekolah, terutama dalam pengelolaan dan pemanfaatan semua kebutuhan sekolah (Myende et al., 2018). Manajemen keuangan sekolah sangat penting dalam hubungannya dengan pelaksanaan kegiatan sekolah (Said, 2018). Seorang kepala sekolah harus memiliki ilmu pengetahuan tentang manajemen, khususnya manajemen keuangan, karena untuk menjalankan seluruh kegiatan yang ada di sekolah tidak terlepas dari pengolahan dana. Dana yang diperoleh atau diberikan oleh pemerintah, maupun pihak lainnya memerlukan manajemen yang baik (Rangongo et al., 2016). Sebesar apapun dana sekolah bila tidak dikelola dengan manajemen yang baik, maka sekolah tersebut akan mengalami suatu kemunduran.

Manajemen keuangan harus ditangani secara serius, sistematis, dan penuh tanggung jawab untuk menghindari hal-hal yang tidak diinginkan, karena manajemen keuangan yang efisien akan memastikan adanya keuntungan bagi lembaga pendidikan (Kenayathulla, 2018). Sebuah lembaga pendidikan yang bagus, tentunya memiliki pengelolaan keuangan yang bagus pula guna mencapai target yang telah ditetapkan bersama. Dalam rangka menciptakan sebuah lembaga pendidikan yang efektif dan efisien melalui pengelolaan keuangan, maka sarana dan prasarana pendidikan yang memadai juga memiliki peran penting dalam mewujudkan tujuan dari pendidikan tersebut (Centerwall \& Nolin, 2019).

Ada beberapa prinsip yang perlu diperhatikan dalam manajemen keuangan sekolah, yaitu prinsip keadilan, efisiensi, transparansi, dan akuntabilitas publik diperlukan dalam pengelolaan dana pendidikan. Sekolah mempunyai pengaturan terkait penyerapan anggaran sekolah yang digunakan dalam menjalankan roda pendidikan di sekolah, baik sekolah yang berstatus negeri maupun swasta.

Fakta di lapangan mengungkapkan bahwa operasional kegiatan sekolah perlu adanya manajemen keuangan dalam mengatur tata kelola penggajian pendidik dan tenaga kependidikan, tenaga tata usaha, memperbaiki/meningkatkan sarana prasarana pendidikan. Untuk membantu dalam masalah pembayaran operasional sekolah, pemerintah memberikan dana yang disebut dengan Bantuan Operasional Sekolah (BOS) (Subkhi Widyatmoko, 2017). BOS diberikan bagi satuan pendidikan di lembaga sekolah/madrasah untuk membantu pembiayaan peserta didik agar mampu menunjang sarana prasarana pendidikan, pemeliharaan dan perbaikan sekolah, biaya ulangan umum harian, biaya honor guru. 
Sarana prasarana yang digunakan dalam menunjang pengelolaan kegiatan belajar mengajar harus memenuhi syarat, agar tujuan pendidikan dapat tercapai. Tanpa adanya sarana prasarana yang memadai pendidikan tidak dapat berjalan secara optimal. Sarana dan prasarana pendidikan perlu dikelola dengan baik serta merupakan bagian yang tidak dapat dipisahkan dari manajemen pendidikan (Latifah, 2017). Seperti gedung, tanah, perlengkapan administrasi sampai pada sarana yang digunakan langsung dalam kegiatan belajar mengajar di kelas yang dapat membantu mempermudah pemahaman peserta didik dalam proses kegiatan pembelajaran di sekolah sehingga lebih bermakna, berkualitas, dan menyenangkan. Tanpa adanya sarana prasarana pendidikan, maka proses pembelajaran akan terhambat dan berpengaruh pada hasil belajar peserta didik.

Penelitian Adillah (2016) menunjukkan bahwa; untuk mendapatkan dana guna memenuhi berbagai kebutuhannya, sekolah harus kreatif dan inovatif dalam memanfaatkan peluang yang ada, baik terhadap wali murid, komite sekolah maupun terhadap pemerintah. Dalam pengelolaannya, menurut (Zahruddin, 2019), sekolah perlu melibatkan stakeholders, baik internal maupun eksternal untuk mengawal sistem keuangan yang ada. Melalui pelibatan tersebut, diharapkan partisipasi aktif masyarakat dalam mengelola sistem keuangan sekolah, mulai dari partisipasi, pemenuhan kebutuhan sekolah, sampai pada pengawasannya.

Dalam mengelola keuangan menurut Tandililing (2019) diperlukan transparansi dan akuntabilitas keuangan sekolah, karena sangat berpengaruh terhadap motivasi mengajar guru. Begitu juga dengan Anam (2019) yang menyatakan dalam penelitiannya bahwa; sumber keuangan sekolah yang didapatkan dari masyarakat harus dikelola dengan baik dan dipertanggungjawabkan kepada masyarakat, agar supaya kepercayaan publik terhadap lembaga pendidikan terus meningkat.

Selanjutnya dalam penelitiannya menegaskan bahwa; manajemen keuangan dalam pengadaan sarana dan prasarana harus dikelola dengan baik, mulai dari perencanaan, pengadaan, penyimpanan, inventarisasi, pemeliharaan dan pemanfaatan, sampai dengan pengawasan.

Penelitian ini hadir dalam rangka memahami dan menganalisis tentang tentang manajemen keuangan sekolah yang dilakukan oleh kepala sekolah, dalam rangka pemenuhan sarana prasarana pendidikan di SD Muhammadiyah 1 Krian, Sidoarjo, Jawa Timur. Keunikan penelitian ini terletak pada budaya keterbukaan, disiplin tinggi, dan pelibatan masyarakat dalam setiap kegiatan sekolah, khususnya dalam aspek manajemen keuangan dan pengelolaan sarana prasarana pendidikan.

\section{METODE PENELITIAN}

Penelitian ini menggunakan pendekatan kualitatif jenis studi kasus. Dalam hal ini, peneliti menganalisis dan memahami manajemen keuangan sekolah yang diterapakan di SD Muhammadiyah 1 Krian, Sidoarjo, Jawa Timur, dalam pemenuhan sarana prasarana pendidikan. Informan dalam penelitian ini terdiri dari pimpinan, sekretaris, dan bendahara. Teknik pengumpulan datanya 
dilakukan melalui; interview, observasi partisipan, dan dokumentasi guna memperoleh informasi yang akurat dari materi yang dikaji. Teknik analisis datanya menggunakan data reduction, data display, and conclusion drawing/verification. Sedangkan pengecekan keabsahan datanya dilakukan melalui; credibility, transferability, dependability, dan confirmability, sehingga data benar-benar akurat dan kredibel.

\section{HASIL DAN PEMBAHASAN}

Berdasarkan data yang didapatkan peneliti di lapangan, maka diperoleh temuan tentang manajemen keuangan sekolah dalam pemenuhan sarana prasarana pendidikan yang diimplementasikan pada SD Muhammadiyah 1 Krian, Sidoarjo, Jawa Timur sebagai berikut;

\section{Perencanaan Anggaran (Budgeting) Sekolah}

Perencanaan anggaran (budgeting) di SD Muhammadiyah 1 Krian merupakan pernyataan mengenai estimasi kinerja yang hendak dicapai selama periode waktu tertentu yang dinyatakan dalam ukuran finansial. Perencanaannya disusun secara secara sistematis, yang meliputi seluruh kegiatan di sekolah, yang dinyatakan dalam satuan keuangan, dan berlaku untuk jangka waktu yang akan datang.

Menurut Arum (2019), proses perencanaan anggaran untuk sarana prasarana di SD Muhammadiyah 1 Krian diawali dengan rapat bersama yang melibatkan para pimpinan, dewan guru, komite sekolah, dan yayasan, terkait dengan perencanaan kebutuhan sarana dalam satu tahun ajaran. Rapat tersebut akan menghasilkan keputusan tentang hal yang berkaitan dengan; hasil evaluasi sarana dan prasarana yang ada, menyusun pengadaan sarana dengan mempertimbangkan skala prioritas, dan mengimplementasikan rencana melalui pengadaan sarana dan prasarana yang dibutuhkan.

Perencanaan anggaran untuk pemenuhan sarana dan prasarana akan ditetapkan dalam Rencana Anggaran Pendapatan dan Belanja Sekolah (RAPBS). Fia (2019) menuturkan bahwa; biasanya di sekolah ini kami mengidentifikasi sumber dana bagi sekolah sebelum menyusun RAPBS. Dari mana saja masukannya dan kemudian untuk apa pengeluarannya. Hal itu dilakukan untuk mengevaluasi kondisi keuangan, mulai menentukan skala prioritas yang harus dipenuhi oleh sekolah, khususnya pemenuhan sarana dan prasarana.

Penetapan anggaran perencanaan untuk biaya sarana prasarana yang diuraikan per item dengan pihak yayasan, sekolah, dan komite yang disusun berdasarkan kesepakatan bersama. Setiap semester tentu ada pengecekan barang yang masih bisa dipakai dan tidak layak pakai sehingga akan ada pengadaan sarana yang sudah habis atau tidak layak pakai. Begitu pun dengan prasarana apabila ada kerusakan tentu akan diperbaiki (Friska, 2019).

Penentuan alokasi anggaran, perlu mempertimbangkan urgensi kebutuhan kegiatannya. Ini menyangkut persoalan waktu, personel, serta jumlah alokasi dana yang tersedia. Sehingga perlu adanya analisis terhadap sumber dana dan nominal yang mungkin didapatkan lembaga untuk setiap kegiatan yang diagendakan. Sumber dana dalam kegiatan sekolah pada 
praktiknya menghasilkan Rencana Kerja Anggaran Sekolah/Madrasah (RKAS/RKAM) (Ratna, 2019).

Berangkat dari hal tersebut, maka perencanaan keuangan sekolah dalam pemenuhan sarana prasarana pendidikan di SD Muhammadiyah 1 Krian, Sidoarjo dapat digambarkan sebagai berikut;

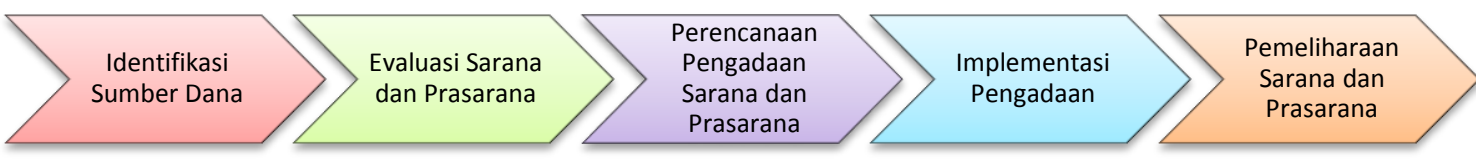

\section{Gambar 1 : Perencanaan keuangan sekolah dalam pemenuhan sarana prasarana}

Dalam penyelenggaraan pendidikan, sumber dana merupakan potensi yang sangat menentukan bagi berjalan tidaknya suatu lembaga pendidikan (Suhartini, 2017), oleh karena itu, diperlukan suatu sistem pengelolaan keuangan yang tepat guna. Penganggaran sebagai bagian awal dari kegiatan manajemen keuangan merupakan satu langkah perencanaan dan juga sebagai instrumen perencanaan yang fundamental (Nanang Fattah, 2016). Anggaran merupakan keseluruhan rincian biaya mengenai pendapatan dan belanja sekolah yang umumnya disusun rutin setiap tahun oleh lembaga dengan melibatkan pihak-pihak terkait, sebagai alat perencanaan maupun pengendalian (Zahruddin et al., 2019).

Penyusunan anggaran merupakan gambaran setiap kegiatan yang direncanakan sekolah agar dapat menentukan satuan biaya di setiap kegiatan sehingga membantu dalam mengarahkan lembaga pendidikan pada pelaksanaan kegiatan-kegiatannya. Adapun fungsi anggaran diklasifikasikan menjadi tiga jenis, yaitu; Pertama, alat penafsir, yaitu memperkirakan besarnya pengeluaran dan pendapatan sehingga mengetahui kebutuhan dana yang dibutuhkan dalam realisasi kegiatan di lembaga pendidikan. Kedua, alat kewenangan, yaitu memberi kewenangan terkait dana yang dikeluarkan untuk membiayai kegiatan sesuai perencanaan anggaran. Ketiga, alat efisiensi, yaitu mengetahui kegiatan pendidikan yang dilaksanakan sesuai perencanaan anggaran secara efisien (Masditou, 2017).

Perencanaan dipahami sebagai serangkaian kegiatan dengan menetapkan tujuan yang diprioritaskan dengan menjabarkannya secara operasional yang dapat diukur, melakukan analisa alternatif untuk tercapainya tujuan dengan analisis cost effectiveness, dan untuk mencapai sasaran dengan melakukan rekomendasi alternatif (Masditou, 2017). Penyusunan rencana anggaran ini merupakan perencanaan sumber dana untuk kegiatan pendidikan dan tercapainya tujuan pendidikan di lembaga sekolah. Adapun dalam penyusunan anggaran pendidikan tentu memperhatikan sumber keuangan yang ada di sekolah, yang terdiri dari; a) pemerintah (pemerintah pusat dan pemerintah daerah); b) orang tua peserta didik; c) masyarakat (Siti Sanisah, 2015).

Perencanaan keuangan sekolah mengacu pada konsep penyelenggaraan pendidikan sekolah secara utuh. Pelayanan di lembaga pendidikan di antaranya; (1) teknik layanan edukatif dalam proses kegiatan belajar mengajar 
baik secara teori maupun praktik dan penilaian hasil belajar, (2) layanan yang menunjang operasional kegiatan ekstrakurikuler dan intrakurikuler, (3) pemeliharaan dan pemanfaatan buku pelajaran, alat pendidikan, alat pelajaran, laboratorium, perpustakaan dan peralatan praktik serta bahan praktik dan keterampilan, (4) pengadaan dan perawatan sarana penunjang seperti sarana administrasi, gedung sekolah, ruang kelas, fasilitas sekolah dan lingkungan; (5) penyediaan daya dan jasa, (6) perjalanan dinas kepala madrasah dan guru, (7) pemberdayaan komite madrasah, kegiatan sosial, dan layanan kemasyarakatan (8) kegiatan lomba yang diikuti peserta didik atau guru, (9) keperluan layanan sekolah yang habis pakai seperti surat kabar, (10) honorarium pendidik dan tenaga kependidikan, asuransi kesehatan, transportasi, dan lain-lain (Anam, 2019).

Peran kepala sekolah untuk menyusun perencanaan yang baik mutlak diperlukan. Pentingnya perencanaan yang baik telah digambarkan di dalam alQuran surat al-Hashr ayat 18 berikut ini.

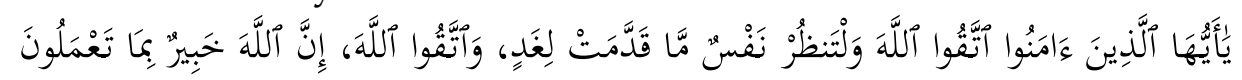

Artinya:

"Hai orang-orang yang beriman, bertakwalah kepada Allah dan hendaklah setiap diri memperhatikan apa yang telah diperbuatnya untuk hari esok, (akhirat), dan bertaqwalah kepada Allah, sesungguhnya Allah Maha mengetahui apa yang kamu kerjakan." (QS. al-Hashr : 59/18)

Berangkat dari ayat tersebut, dapat diketahui bahwa peran pemimpin dalam menyusun perencanaan sangatlah besar. Baik tidaknya sistem keuangan pada suatu lembaga pendidikan, tergantung kepada perencanaan yang telah ditentukan bersama dengan asas keterbukaan, efektifitas, dan efisiensi.

\section{Penyerapan Anggaran Sekolah}

Penyerapan anggaran di SD Muhammadiyah 1 Krian, Sidoarjo menggambarkan kemampuan sekolah dalam melaksanakan dan mempertanggungjawabkan setiap kegiatan yang merupakan akumulasi dari penyerapan anggaraan yang dilakukan oleh lembaga.

Menurut Ratna (2019) penyerapan anggaran di SD Muhammadiyah 1 Krian telah berjalan dengan baik. Artinya perencanaan yang telah ditentukan melalui RAPBS dilaksanakan sesuai dengan SOP yang ada di sekolah. Artinya, apabila ada anggaran yang mau dikeluarkan, maka diperlukan persetujuan dari pimpinan. Apabila berkaitan dengan sarana dan prasarana, maka harus berhubungan dengan penanggung jawab sarana dan prasarana

Hal senada juga disampaikan oleh Fia (2019), pengeluaran anggaran di sekolah seperti pengembangan buku di perpustakaan, belanja barang habis dipakai, pembelian LCD, pembangunan gedung baru, harus mendapatkan persetujuan dari pihak sekolah, untuk disesuaikan dengan perencanaan anggaran sekolah. Biasanya hal tersebut diadakan rapat terlebih dahulu dengan yayasan, komite sekolah, leader, dan stakeholder.

Sesuai dengan hasil observasi peneliti di SD Muhammadiyah 1 Krian, penyerapan anggaran di SD Muhammadiyah 1 Krian, Sidoarjo dilaksanakan secara transparan dan dipertanggungjawabkan laporannya. Hal ini dibuktikan 
dengan adanya pengajuan anggaran dari unit yang akan mengadakan sarana dan prasarana terkait dengan kebutuhannya, adanya disposisi dari kepala sekolah, adanya bukti dan laporan keuangan pasca pengadaan sarana dan prasarana.

Adanya transparansi keuangan di SD Muhammadiyah 1 Krian dibenarkan oleh Friska, S. (2019) melalui penuturannya bahwa; transparansi dan akutabilitas keuangan menjadi prinsip pengelolaan keuangan di lembaga kami. Hal ini sudah menjadi aturan di lembaga ini sejak lama. Bahkan petunjuk dan teknis pengajuan, pencairan, dan pembuatan laporan keuangan telah dibuat oleh team beberapa tahun lalu.

Dalam hal ini, sekolah harus bisa meningkatkan kesadaran semua warga sekolah dan masyarakat dalam hal pendanaan untuk pemenuhan sarana prasarana pendidikan yang manfaatnya dapat dirasakan untuk peserta didik yang notabene anak dari para orang tua tersebut. Pengeluaran keuangan harus dikontrol atau disetujui oleh pihak komite sekolah. Pemanfaatan anggaran yang dikeluarkan disesuaikan dengan rencana yang diajukan untuk memenuhi sarana prasarana pendidikan.

Penyerapan anggaran merupakan kemampuan unit pengeluaran (satuan kerja) untuk memanfaatkan anggaran yang telah ditentukan untuk mencapai output yang direncanakan secara tepat waktu (Fajar \& Arfan, 2017). Penyerapan anggaran merupakan dana yang dikeluarkan harus berdasarkan kebutuhan sesuai dengan perencanaan secara efektif dan efisien (Rahmadani \& Anisa, 2017). Setiap pengeluaran harus dibukukan dan bendahara bertanggung jawab dalam melakukan pembukuan sesuai pengeluaran waktu dana anggaran.

Kegagalan target penyerapan anggaran pada lembaga pendidikan akan berakibat pada hilangnya manfaat belanja, karena dana yang dialokasikan ternyata tidak semuanya dapat dimanfaatkan oleh sekolah. Hal ini menunjukkan bahwa dana yang ada menganggur (idle money), karena tidak digunakan dengan baik (Ruhmaini, 2019). Apabila pengalokasian anggaran efisien, maka keterbatasan sumber dana yang dimiliki sekolah dapat dioptimalkan untuk mendanai kegiatan stategis.

Penyerapan anggaran harus mendapatkan perhatian serius dari semua pihak, utamanya bendahara sekolah sebagai penanggung jawab teknis dalam hal ini. Bendaharawan merupakan tenaga kependidikan yang berwenang dalam penyimpanan, pengeluaran biaya atau bukti-bukti pengeluaran anggaran dan diwajibkan membuat perhitungan dan pertanggungjawaban (Subkhi Widyatmoko, 2017). Secara konseptual, banyak pendekatan yang bisa digunakan dalam penerimaan manajemen keuangan, tetapi ada karakteristik yang khas dalam penyelenggaraan pendidikan di madrasah/sekolah.

Sebagai bendahara sekolah, Masyhud (2013) berpendapat bahwa; pelaksanaan keuangan sekolah harus memperhatikan hal-hal berikut ini, di antaranya; pertama, bendahara membuat laporan keuangan sekolah dan diserahkan kepada kepala sekolah untuk dicocokkan RAPBS di setiap akhir tahun anggaran. Kedua, pengeluaran anggaran sekolah harus ada lampiran bukti-bukti kuitansi atau bukti penyetoran pajak bila ada. Ketiga, kuitansi tanda tangan penerima honorarium atau bukti lain dari bantuan yang sah. Keempat, 
bukti pengeluaran anggaran sekolah ditunjukkan untuk diperiksa oleh komite sekolah terkait akuntabilitas keuangan sekolah.

\section{Pembukuan (Accounting) Keuangan Sekolah}

Pembukuan keuangan di SD Muhammadiyah 1 Krian, Sidoarjo merupakan suatu proses pencatatan yang dilakukan secara teratur oleh bendahara untuk mengumpulkan data dan informasi keuangan yang meliputi pencatatan terhadap alur keuangan yang ada, khususnya dalam pemenuhan sarana dan prasarana pendidikan, baik secara langsung maupun tidak langsung.

Kegiatan pembukuan keuangan di SD Muhammadiyah 1 Krian, Sidoarjo, menurut Ratna (2019) berjalan dengan baik, artinya penanggung jawab keuangan telah melakukan tugas dan fungsinya sesuai dengan prosedur yang ada, mulai dari menerima pengajuan, pemberian disposisi oleh kepala sekolah, pencairan keuangan, sampai pada pelaporan keuangan. Begitu juga dengan pembukuan keuangan yang berhubungan dengan pemenuhan sarana dan prasarana pendidikan.

Menurut Fia (2019), semua daftar barang yang sudah dibeli untuk kegiatan belajar mengajar tercatat dan tersimpan dengan rapi dalam buku kas milik sekolah. Begitu juga dengan pengadaan sarana penunjang lainnya, bendahara membuat laporannya dengan sangat apik, dan telah mendapatkan pengesahan dari kepala sekolah. Pembukuan tersebut selanjutnya akan dijadikan sebagai referensi untuk melakukan evaluasi keuangan secara periodik bersama dengan yayasan, kepala sekolah, dan komite sekolah.

Begitu juga dengan penuturan Arum (2019), sarana prasarana pendidikan sangat penting sebagai penunjang hasil belajar peserta didik, yang mana di lembaga ini pemenuhan sarana tersebut menggunakan dana anggaran sekolah, yang setiap pembeliannya harus ada tanda bukti berupa nota dan pelaporan terlebih dahulu kepada pihak lembaga. Sehingga administrasi keuangan dan sarana prasarana berjalan dengan tertib, mempermudah dalam pemeliharaan, dan pengawasan serta menyediakan data dan informasi untuk perencanaan pengadaan dan pemeliharaan barang sesuai dengan kebutuhan yang akan datang.

Pembukuan keuangan sekolah akan memudahkan pengadministrasian, pembuatan laporan berhubungan dengan sarana prasarana pendidikan dan pencatatan barang perlengkapan yang dimiliki sekolah agar terkontrol dan terawasi secara rinci sehingga memudahkan untuk kebutuhan seperti pelaporan sarana prasarana pendidikan.

Ada dua hal yang harus diperhatikan dalam pembukuan keuangan sekolah, yaitu pertama kewenangan yang menyangkut tentang pengurusan kebijakan penerimaan dan pengeluaran uang. Kedua, tindak lanjut dalam penerimaan, penyimpanan, dan pengeluaran uang dalam pengelolaan anggaran, dibutuhkan arahan dan bimbingan dari kepala sekolah kepada seluruh staf dalam pengelolaan keuangan sekolah (Komariah, 2018). Seorang manajer pendidikan harus mampu memahami dan menjelaskan kepada staf terkait fungsi, tujuan, dan manfaat pembukuan keuangan sekolah, di antaranya; 
Pertama, buku pos (vate book) digunakan untuk memberikan informasi pembelajaan uang harian agar manajer pendidikan mudah dalam memeriksa anggaran yang ke luar sesuai dengan rencana anggaran pendidikan (Arwildayanto, Lamatenggo, \& Sumar, 2017). Kedua, faktur yang berupa buku atau lembaran yang diarsipkan sebagai pertanggungjawaban penggunaan uang secara umum. Ketiga, buku kas sebagai pencatatan perincian pemasukan dan pengeluaran dana di lembaga dalam memenuhi sarana prasarana pendidikan, seperti pembelian LCD, whiteboard, boardmarker, dan kebutuhan lainnya. Pencatatan di buku kas harus sesuai dengan cek yang diterima dan dikeluarkan dalam pembelajaan sekolah. Keempat, lembar cek sebagai bukti transaksi pemesanan barang dan kepala sekolah atau bendahara yang berhak menandatanganinya. Kelima, buku besar atau buku induk yang perlu ditunjukkan kepada kepala sekolah setiap akhir bulan terkait penyerapan anggaran. Keenam, pembayaran SPP peserta didik yang tercatat di buku kas pembayaran uang sekolah harus disesuaikan dengan tanggal pembayarannya, baik yang sudah membayar atau pun yang memiliki tunggakan pembayaran untuk mengantisipasi dari kwitansi yang hilang (Prakoso \& Herlawati, 2017). Ketujuh, neraca percobaan sebagai upaya pertanggungjawaban keuangan lembaga pendidikan selama tahun anggaran sehingga pengeluaran dan skala prioritas kegiatan dapat terlaksana dengan baik.

\section{Pertanggungjawaban (Akuntabilitas) Keuangan Sekolah}

Akuntabilitas keuangan di SD Muhammadiyah 1 Krian, Sidoarjo dipahami sebagai pertanggungjawaban yang dilakukan oleh seseorang terhadap segala tindakannya - khususnya yang berkaitan dengan keuangan kepada orang yang memberi wewenang.

Berdasarkan perencanaan yang telah ditetapkan oleh sekolah, maka pihak sekolah membelanjakan uang untuk pemenuhan sarana dan prasarana sekolah secara bertanggung jawab, dan dilaporkan kepada kepala sekolah, yayasan, orang tua, masyarakat dan pemerintah.

Menurut Fia (2019), pertanggungjawaban keuangan sekolah dalam pemenuhan sarana prasarana pendidikan ada di buku kas harian yang dibuat oleh bendahara sekolah, buku kontrol keuangan yang disampaikan kepada kepala sekolah dan stakeholders pada saat rapat bulanan, tri wulan, dan akhir tahun pelajaran.

Begitu juga dengan penuturan Friska (2019), bahwa pelaporan pertanggungjawaban di SD Muhammadiyah 1 Krian dilakukan pada akhir tahun, dengan menghadirkan wali murid. Dan di akhir tahun ajaran dibahas RAPBS untuk sarana prasarana pendidikan dengan pihak yayasan, komite sekolah, pihak sekolah guna pertanggungjawaban kesesuaian dengan perencanaan anggaran.

Berdasarkan hasil observasi peneliti di lapangan, didapatkan bahwa pertanggungjawaban keuangan sekolah dalam skala kecil dilakukan oleh bendara dengan cara melaporkan kondisi keuangan kepada kepala sekolah. Sedangkan pertanggungjawaban dalam skala besar, laporan keuangan 
disampaikan setiap akhir tahun pada rapat sekolah, dengan menghadirkan wali murid.

Begitu juga dengan pernyataan Arum, A. (2019), yang menyatakan bahwa; keuangan sekolah merupakan satu kesatuan yang tidak dapat terpisahkan dari aspek lainnya. Semakin baik kondisi keuangan di lembaga ini, maka semakin baik pula kemampuan sekolah dalam mendanai berbagai keperluan sekolah, terutama dalam pemenuhan sarana prasarana pendidikan guna menunjang proses pembelajaran di sekolah dan demi tercapainya tujuan pendidikan. Sebaliknya, sekolah yang tidak memiliki keuangan yang cukup, maka sekolah tidak akan mampu melaksanakan kegiatan sekolah sesuai dengan yang direncanakan.

Berangkat dari hal tersebut di atas, dapat dipahami bahwa akuntabilitas merupakan kemampuan dalam memberikan informasi, penjelasan, pertanggungjawaban kinerja kepada pihak-pihak yang bekepentingan (stakeholders) (Fattah, 2016). Akuntabilitas merupakan kondisi seseorang yang dinilai oleh orang lain karena kualitas performansinya dalam menyelesaikan tugas untuk mencapai tujuan yang menjadi tanggung jawabnya. Lebih lanjut akuntabilitas dapat dilihat dari sudut pandang pengendalian tindakan pada pencapaian tujuan (Mubin, 2018).

Pelaksanaan pertanggungjawaban ini juga bagian dari pengawasan yang dapat dilakukan berdasarkan kebutuhan dan kewenangan. Hal ini dilakukan mulai dari proses pengeluaran, pos anggaran pembelanjaan, perhitungan dan penyimpangan barang oleh petugas yang ditunjuk. Secara periodik perlu adanya akuntabilitas laporan tahunan dan laporan masa akhir jabatan pimpinan kepada stakeholder.

Pertanggungjawaban penerimaan dan penggunaan keuangan lembaga pendidikan dilaksanakan dalam bentuk laporan bulanan dan triwulan, ditujukan kepada antara lain: a) kepala dinas pendidikan, b) kepala Badan Administrasi Keuangan Daerah (BAKD), 3) dinas pendidikan di kecamatan dan lainnya (Komariah, 2018). Pertanggungjawaban keuangan sekolah sebagai sebuah laporan keuangan dari keseluruhan pembiayaan kegiatan sekolah. Laporan dilakukan oleh bendahara dan staf sekolah. Laporan keuangan berisikan tentang pemasukan, pengeluaran dan pemakaian biaya.

Akuntabilitas di dalam manajemen keuangan berarti penggunaan uang sekolah dapat dipertanggungjawabkan sesuai dengan perencanaan yang telah ditetapkan (Molchanova, 2019). Berdasarkan perencanaan yang telah ditetapkan dan peraturan yang berlaku maka pihak sekolah membelanjakan uang secara bertanggung jawab. Pertanggungjawaban dapat dilakukan kepada orang tua, masyarakat, dan pemerintah. Ada tiga pilar utama yang menjadi prasyarat terbangunnya akuntabilitas, yaitu; 1) transparansi para penyelenggara sekolah melalui pelibatan terhadap berbagai komponen dalam pendidikan, 2) adanya standar kinerja di setiap institusi yang dapat diukur dalam melaksanakan tugas, fungsi dan wewenangnya, 3) adanya partisipasi untuk menciptakan suasana kondusif dalam menciptakan pelayanan yang prima dan pelayanan yang cepat (Lilik Huriyah, 2014). 
Melalui akuntabilitas keuangan di sekolah, kepercayaan masyarakat terhadap sekolah akan meningkat (Tandililing, 2019). Pengelolaan manajemen sekolah yang baik akan memberikan dampak positif terhadap kepercayaan publik (Radzi, 2010). Dengan demikian dapat dimaknai bahwa, terciptanya kepercayaan publik akan selalu berbanding lurus dengan apa yang telah dilakukan dan diupayakan oleh sekolah dalam memenuhi kebutuhan publik. Selain itu, akuntabilitas ditujukan untuk menilai kinerja sekolah dan kepuasan publik terhadap mutu layanan pendidikan, melalui pelibatan masyarakat dalam kegiatan pengawasan pelayanan pendidikan.

\section{KESIMPULAN}

Manajemen keuangan sekolah yang matang perlu dimiliki oleh sekolah, agar supaya pemasukan dan pengeluaran uang sekolah dapat berjalan dengan baik, sehingga pemenuhan sarana prasarana pendidikan bisa terpenuhi. Oleh karenanya, peran kepala sekolah sebagai leader harus mampu memahami kondisi sekolah dan mampu mengelola dua aspek ini dengan baik. Dengan adanya dana yang dimiliki sekolah dan sarana prasarana yang memadai, akan dapat menunjang proses belajar mengajar, sehingga tujuan pendidikan dapat terwujud dengan baik dan optimal.

Melalui hasil penelitian ini, hal yang harus dilakukan oleh sekolah dalam mengelola keuangan di lembaga pendidikan harus didasarkan pada open management dengan cara melibatkan masyarakat public sebagai agent of control, agar tercipta pelayanan yang berkualitas dan mampu memberikan kepuasan kepada semua pihak. Sedangkan dalam kaitannya dengan pemenuhan sarana dan prasarana pendidikan, hal yang harus diperhatikan adalah pentingnya pemeliharaan sarana dan prasarana yang sudah ada dan akan diadakan. Pemeliharaan merupakan pekerjaan yang sangat sulit dilakukan, apabila tidak didasarkan pada kesungguhan dalam sistem manajemen sarana dan prasarana. Perlu ada pengawalan khusus terhadap sarana dan prasarana yang dimiliki sekolah, sehingga penggunaannya efektif dan efisien.

\section{DAFTAR PUSTAKA}

Adillah, G. (2016). Manajemen Keuangan Sekolah. Manajer Pendidikan, 10(4), 343-346.

Anam, K. (2019). Manajemen Keuangan Madrasah yang Bersumber dari Masyarakat. At-Turats, 13(1), 56-75.

Arum, A. (2019). Interview. Krian, Sidoarjo, Jawa Timur.

Arwildayanto, Lamatenggo, N., \& Sumar, W. T. (2017). Manajemen Keuangan dan Pembiayaan Pendidikan. Padjadjaran: Widya Padjadjaran.

Burger, R. H., Kaufman, P. T., \& Atkinson, A. L. (2015). Disturbingly Weak: The Current State of Financial Management Education in Library and Information Science Curricula. Journal of Education for Library and Information Science, 56(3), 13-16. 
Centerwall, U., \& Nolin, J. (2019). Using an Infrastructure Perspective to Conceptualise The Visibility of School Libraries in Sweden. Information Research, 24(3), 1-30.

Fajar, N., \& Arfan, M. (2017). Analisis Penyerapan Anggaran Pada Satuan Kerja

Perangkat Aceh. Jurnal Telaah dan Riset Akuntansi, 10(2), 95-102.

Fattah, Nanang. (2016). Landasan Manajemen Pendidikan. Bandung: PT Remaja Rosdakarya.

Fia, B. (2019). Interview. Krian, Sidoarjo, Jawa Timur.

Friska, S. (2019). Interview. Krian, Sidoarjo, Jawa Timur.

Komariah, N. (2018). Konsep Manajemen Keuangan Pendidikan. Jurnal AlAfkar, 6(1), 67-93.

Latifah, Purwanti, E., \& Kusuma, N. (2017). Peran Manajemen Keuangan dalam Pengadaan Sarana dan Prasarana Pendidikan di MTs Negeri 2 Pringsewu Kecamatan Banyumas. Jurnal Manajamen Pendidikan Islam, 2(1), 9-14.

Huriyah, Lilik. (2014). Manajemen Keuangan: Optimalisasi Pengelolaan Keuangan di Lembaga Penddikan Islam. Surabaya: UINSA Pers.

Masditou. (2017). Manajemen Pembiayaan Pendidikan Menuju Pendidikan yang Bermutu. Jurnal Ansiru PAI, 1(2), 119-145.

Masyhud, S. (2013). Manajemen Pondok Pesantren. Jakarta: Diva Pustaka.

Molchanova, V. S., \& Federation, R. (2019). Education and Financial Inclusion. An Empirical Study in Students of Higher Education. European Journal of Contemporary Education, 8(4), 810-818.

Mubin, N. (2018). Integritas dan Akuntabilitas dalam Pengelolaan Keuangan Sekolah/Madrasah. At-Taqwa, 14(2), 80-92.

Myende, P. E., Samuel, M. A., \& Pillay, A. (2018). Novice Rural Principals ' Successful Leadership Practices in Financial Management: Multiple Accountabilities. South African Journal of Education, 38(2), 1-11.

Prakoso, M. D., \& Herlawati. (2017). Sistem Informasi Pembayaran Biaya Pendidikan Siswa pada SMK Perwira Bekasi Utara. Bina Insani ICT Journal, 4(1), 95-110.

Radzi, N. M., Ghani, M. F. A., Siraj, S., \& Afshari, M. (2010). Financial Decentralization in Malaysian Schools: Strategies for Effective Implementation. The Malaysian Online Journal of Educational Science, 1(3), 20-32.

Rahmadani, D., \& Anisa, I. Z. (2017). Pengaruh Perencanaan Anggaran,Kualitas Sumber Daya Manusia dan Pelaksanaan Anggaran. Jurnal Riset Akuntansi, 10(1), 134-148.

Rangongo, P., Mohlakwana, M., \& Beckmann, J. (2016). Causes of Financial Mismanagement in South African Public Schools: The Views of Role Players. South African Journal of Education, 36(3), 1-10.

Ratna, M. (2019). Interview. Krian, Sidoarjo, Jawa Timur.

Ruhmaini, R., Abdullah, S., \& Darwanis, D. (2019). Analisis Serapan Anggaran Belanja Pemerintah Kabupaten Aceh Tengah. Jurnal Perspektif Ekonomi Darussalam, 4(1), 31-43. 
Said, A. (2018). Kepemimpinan Kepala Sekolah dalam Melestarikan Budaya Mutu Sekolah. Evaluasi, 2(1), 257-273.

Sanisah, Siti. (2015). Kebijakan Pengelolaan Anggaran Pendidikan di Kabupaten Lombok Tengah. Jurnal Pendidikan Ekonomi dan Bisnis Vol., 3(1), 101-118.

Suhartini, H. (2017). Pengaruh Pelaksanaan Kebijakan Rencana Kerja dan Anggaran Sekolah terhadap Manajemen Sekolah dalam Mewujudkan Efektifitas Penggunaan Anggaran Dana Sekolah. Khazanah Akademia, 1(1), 71-81.

Tandililing, J. (2019). Pengaruh Transparansi dan Akuntabilitas Keuangan Sekolah terhadap Motivasi Mengajar Guru di Kabupaten Keerom. Jurnal Kajian Ekonomi \& Keuangan Daerah, 4(2), 38-57.

Widyatmoko, Subkhi, S. (2017). Pengelolaan Dana Bantuan Operasional Sekolah di SDN Kemasan I Surakarta. Manajemen Pendidikan, 12(1), 153160.

Zahruddin, Arifin, Z., \& Suhandi, A. (2019). Implementasi Penyususnan Rencana Anggaran Pendapatan dan Belanja Sekolah. Jurnal Administarsi Pendidikan, 26(1), 45-56. 